ISSN : 1978-4333, Vol. 03, No. 02

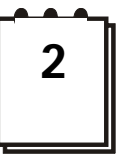

\title{
Percobaan Pembangunan Partisipatif dalam Otonomi Daerah
}

\author{
Ivanovich Agusta ${ }^{1}$
}

\begin{abstract}
As part of governing mechanism, local participation has already been practiced by numerous ethnic groups of Indonesia since centuries. In modern era, the idea of participation, that was at the outset integrated into development thought as desentralisation, was introduced in 1950s-1960s. In the 1980s, Non-Government Organization adopted participatory development to control government and donor agencies. Since 1990s, donor and developed countries adopted paticipatory development as single approach to operationalize development measures. In Indonesia, participatory development practices need to pay attention on two substructures, i.e., program and budget arrangements. Musyawarah Perencanaan Pembangunan (musrenbang) is a participatory-based planning mechanism is run stretching from rural upto national level and is considered to be very central for nation-wide development measures. The mechanism needs to be criticed since it just increases efficiency and effectiveness of development actions, but it fails to expand participaton space of the lowest social layers of rural communities.
\end{abstract}

Keywords: participatory development, participatory development paradigm, Musyawarah Perencanaan Pembangunan

\section{Relevansi Pembangunan Partisipatif}

Pendekatan pembangunan partisipatif (participatory development) ${ }^{2}$ saat ini semakin relevan. Yang menarik, relevansi dapat ditarik dari kutub-kutub yang berlawanan,

1 Sosiolog pedesaan Institut Pertanian Bogor. Email iagusta@hotmail.com, web blog www.ivanagusta.wordpress.com.

2 Sebagian peneliti membedakan antara participatory development yang dinilai bersifat top down dan dikenalkan oleh elite, dari participation-in-development yang dinilai bersifat bottom up dan dikelola dari rakyat (Kumar, 2002). Pembedaan tersebut bermakna ketika digunakan untuk mengkaji suatu "proyek" pembangunan. Akan tetapi tulisan ini tidak mengarah kepada kajian "proyek", melainkan lebih mengarah kepada kajian "birokrasi" pemerintahan, sehingga konsep participatory development lebih operasional untuk digunakan dalam arti seluas-luasnya (termasuk dalam pendekatan bottom-up). 
yaitu antara pendukung dan penolak intervensi donor (institusi maupun negara maju) bagi negara sedang berkembang. Kedua kutub ini perlu senantiasa dicermati dalam keseluruhan rangkaian pembahasan di sini karena telah menghasilkan tipe pembangunan partisipatif yang berbeda-beda.

Bagi pendukung pembangunan, pendekatan partisipatif semakin relevan (Canadian International Development Agency, 1997; United States Agency for International Development, 1999; World Bank, 1996; World Bank Operations Policy Department, 1994; Jennings, 2000), karena, pertama, telah terjadi perubahan strategi dari pertumbuhan ekonomi pada tahun 1950-an menjadi program penyesuaian struktural (SAP, Structural Adjustment Program) oleh World Bank dan IMF, serta pembangunan yang berkelanjutan (sustainable development) oleh negara-negara Eropa sejak akhir 1980-an. Konsekuensinya diperlukan partisipasi rakyat untuk meningkatkan efisiensi dan efektivitas utang luar negeri .

Kedua, strategi partisipatif disusun untuk meningkatkan kapasitas rakyat di negara sedang berkembang seraya meninggalkan konflik ideologis Barat-Timur. Melalui partisipasi rakyat diharapkan utang luar negeri bisa menghasilkan efek yang lebih terlihat, melindungi hak asasi manusia, dan meningkatkan demokratisasi. Donor pun dapat semakin aktif memasuki ranah reformasi sistem politik, kebijakan dan struktur penerapan utang di negara sedang berkembang.

Ketiga, sejak 1980-an muncul kecenderungan global ke arah demokratisasi dan pluralisme, liberalisasi ekonomi, dan transisi menuju masyarakat pasar, meskipun kecenderungan ini berbeda-beda dari negara atau wilayah yang satu ke yang lain. Dalam terang pandangan ini, perhatian lebih ditekankan kepada perluasan partisipasi rakyat.

Bagi pihak yang kritis pun (Chambers, 1987, 1993; Cooke dan Kothari, 2001; Friedmann, 1992; McMichael, 2004; Sajogyo, 2006; Sanderson dan Kindon, 2004), pembangunan partisipatif dipandang kian relevan karena, pertama, setelah Perang Dingin berikut kritik besar-besaran terhadap pembangunan, berupa protes LSM (Lembaga Swadaya Masyarakat atau NGO/Non-Governmental Organization) di tingkat lokal hingga internasional sampai gerakan terorisme yang menghancurkan gedung kembar WTC (World Trade Center) pada tanggal 11 September 2001, kini institusi dan negara donor tetap memberikan utangan. Melalui globalisasi, utang luar negeri memungkinkan terjaganya kepentingan negara donor untuk mengelola negara-negara sedang berkembang, atau dikonsepkan sebagai global governance. Partisipasi rakyat dipandang sebagai perisai penting untuk mempertahankan kepentingan negara sedang berkembang di masa mendatang.

Kedua, konsekuensi utangan baru ialah perhatian terhadap efektivitas pemerintah dan perhatian terhadap komunitas. Pemberian utangan baru didasarkan pada alasan yang berbeda dari masa sebelum 1980-an, yaitu jika negara miskin tidak dibangun maka orang miskin akan memasuki negara maju. ${ }^{3}$ Konsekuensinya kini utang

3 Jika pembangunan pada akhir 1940-an memperoleh momentum dari pidato Presiden Amerika Serikat, Harry Truman (Esteva, 1992), kini pada awal abad ke 21 penyampaian utang kepada negara miskin memperoleh momentum dari Perdana Menteri Denmark, Poul Nyrup Rasmussen usai Perang Dingin pada awal 1990-an (McMichael, 2003), "We have a good argument now, a very concrete one, for ordinary people, which is, if you don't help 
didasarkan kepentingan agar pemerintahan negara sedang berkembang mampu menjaga efektivitas dan efisiensi pemerintahan yang dikonseptualisasikan sebagai good governance. Di sini partisipasi rakyat dinilai penting untuk membawa good governance lebih berpihak kepadanya.

Ketiga, perhatian yang besar terhadap komunitas dan kelompok-kelompok yang selama ini tersingkirkan diarahkan untuk menstabilkan mereka. Secara khusus perhatian kepada komunitas, biasanya dalam bentuk desentralisasi, diarahkan untuk menstabilkan komunitas itu sendiri. Selanjutnya perhatian kepada kelompokkelompok yang selama ini tersingkirkan, yaitu perempuan, orang miskin, dan kelompok tersingkir lainnya, diarahkan untuk menanggulangi protes mereka atas kerugian yang di masa lalu, saat ini, maupun di masa mendatang dari pembangunan yang bersifat global.

Relevansi penting lainnya ialah upaya untuk mengalihkan pola pembangunan partisipatif dari basis proyek menuju basis birokrasi. Jika dibandingkan dengan pengalaman pembangunan partisipatif di dunia selama ini yang hampir selalu berbasis keproyekan, maka upaya untuk mengubahnya menjadi basis birokrasi memberikan makna strategis bagi pembangunan Indonesia di masa mendatang. Berbeda dari pandangan yang menyangsikan basis birokrasi -misalnya kekhawatiran akan korupsi, kolusi dan nepotisme - sebenarnya perubahan basis pembangunan ini memiliki makna strategis, karena memungkinkan pembangunan berlangsung secara berkelanjutan (melebihi jangka waktu keproyekan) dan meliputi seluruh warganegara Indonesia (melebihi sasaran proyek semata).

Tulisan ini berupaya mengembangkan konsep pembangunan partisipatif yang lebih sesuai untuk Indonesia. Oleh sebab itu dipelajari terlebih dahulu sejarahnya pada tataran global dan nasional. Dipahami pula landasan hukum dan kebijakan untuk membuka peluang bagi praktek pembangunan partisipatif. Akhirnya dievaluasi praktek yang sementara ini berlaku pada Program Pengembangan Sistem Pembangunan Partisipatif (P2SPP).

\section{Metode Penelitian}

Penelitian ini menggunakan metode kualitatif. Penelitian lapangan dilaksanakan pada bulan September-Desember 2007, sedangkan analisis masih berlangsung hingga tahun 2008. Ranah penelitian terbagi dua, yaitu, pertama, analisis dokumen kebijakan yang berkaitan dengan otonomi daerah dan partisipasi. Dokumen tersebut meliputi peraturan dan perundangan di tingkat pusat, provinsi, kabupaten, dan desa. Diteliti pula konsep dan hasil evaluasi otonomi daerah untuk kasus-kasus kabupaten dan kota di Indonesia.

Kedua, studi lapangan. Lokasi penelitian lapangan terdiri dari kabupaten lokasi pilot project P2SPP tahun anggaran 2006 yaitu Boyolali (Jawa Tengah), Ngada (Nusa Tenggara Timur), Minahasa Selatan (Sulawesi Utara) dan Batanghari (Jambi). Responden penelitian ialah pemanfaat dan pelaksana program. Wawancara mendalam dilaksanakan bersama masing-masing responden. Wawancara

northern Africa, if you don't help eastern and central Europe with a little part of your welfare, then you will have these poor people in your society". 
dikembangkan untuk menggali konsep lokal yang berbeda-beda menurut ragam paradigma pembangunan partisipatif yang dikembangkan oleh pemerintah daerah setempat. Analisis ragam konsep lokal dibedakan menurut paradigma partisipatif dalam argumen proses, efisiensi-biaya, efektivitas, dan hak orang miskin. Analisis diawali dengan perumusan potensi dan permasalahan lokal, perumusan kekhasan konsep-konsep lokal partisipasi untuk tiap paradigma, kemudian diakhiri dengan lokakarya partisipatif di tingkat desa, kabupaten, provinsi dan nasional.

\section{Sejarah Pembangunan Partisipatif}

Dalam kondisi paling awal, bentuk-bentuk demokratis dalam pengambilan keputusan telah ada pada banyak kebudayaan lokal (Siregar dan Wahono, eds, 2002). Pengetahuan ini menunjukkan peluang pembangunan partisipatif dalam suatu otonomi daerah. Di Jawa, misalnya, sebelum terbentuk suatu kerajaan besar yang kuat mulai Abad ke 7, sesungguhnya pusat kekuasaan tersebar di antara desa-desa yang ada. Adapun pola kepemimpinan di tingkat desa tersebut bersifat kolektif, mengikuti kaidah primus inter pares (posisi pemimpin hanya sedikit lebih tinggi dari sesamanya). Pola serupa berlangsung pula pada suku lain di Indonesia yang belum menyusun kerajaan secara besar dan kuat, bahkan sampai saat ini. Contohnya pada suku-suku bangsa di pedalaman Pulau Papua, Sumatera, Kalimantan, Sulawesi.

Pola pembangunan partisipatif yang modern secara internasional baru muncul pada dekade 1950-1960-an (Rahnema, 1992). Dapat dinyatakan bahwa konteks pembangunan partisipatif kala itu berupa desentralisasi, yang memiliki jalur birokrasi kenegaraan. Pada masa pasca Perang Dunia II ini pemerintah dari negara yang baru merdeka (Asia, Afrika) memperhitungkan komunitas lokal untuk memobilisasi penduduk. Pada saat itulah daerah diikutsertakan dalam pengambilan keputusan di tingkat nasional, atau pertanggungjawaban pemerintahan di daerah diserahkan kepada pemerintah setempat.

Dalam sejarah Indonesia, masa ini ditandai oleh "demokrasi parlementer". Diawali sejak proklamasi kemerdekaan, upaya daerah untuk mendukung kemerdekaan diwujudkan dengan sumbangan dan solidaritas daerah kepada sesama warganegara Indonesia (The, 1993). Contohnya tercatat sumbangan pesawat dari Aceh. Juga sempat muncul pemerintahan sementara di Sumatera. Masa partisipasi daerah ini diakhiri dengan tanda-tanda pemberontakan lokal. Pemberontakan tersebut menandai protes daerah kepada pemusatan kekuasaan di Jakarta.

Pada dekade berikutnya konteks pembangunan partisipatif berubah, menjadi konteks proyek-proyek pembangunan (Esteva, 1992). Pada dekade 1970-an tersebut, pelembagaan pembangunan partisipatif dilaksanakan untuk merespons kesalahan dalam proyek yang besar, berbiaya tinggi, dan berpola top-down. Jika sejak akhir 1960-an proyek pembangunan bendungan maupun jaringan listrik, misalnya, dilaksanakan secara besar-besaran, menggunakan sumber dana berupa utang luar negeri yang sangat besar, bahkan menggunakan kontraktor internasional yang berasal dari negara donor, namun hanya memberikan keuntungan rendah bagi masyarakat setempat (dimitoskan dalam mekanisme trickle-down effect). Tidak mengherankan pada dekade 1970-an pembangunan partisipatif muncul sebagai respons atas pemborosan hal-hal tersebut. 
Arah respons ini ditujukan untuk mengubah fokus dari pembangunan infrastruktur menjadi pembangunan berbasis manusia (people-centered development). Konferensi tentang lingkungan maupun pembangunan alternatif yang banyak berlangsung pada saat itu memusatkan perhatian pada pembangunan yang mempertimbangkan suku setempat (ethno-development). Pihak lainnya mengenalkan pembangunan alternatif atau pembangunan (alternative development) yang berpusat pada manusia/rakyat (people-centered development). Pendekatan yang kemudian lebih terkenal berupa bottom-up dan basic needs. Pendekatan bottom-up bukan sekedar mengubah alur pengambilan keputusan dari pihak teknolog dan birokrat menuju pihak rakyat, namun sekaligus mengakui kepandaian atau kearifan rakyat sendiri untuk membangun lingkungannya.

Adapun pendekatan basic needs (pemenuhan kebutuhan dasar) meliputi kebutuhan minimum rumahtangga bagi konsumsi pribadi (makanan, pakaian, perumahan, dsb) (Friedmann, 1992). Kebutuhan lainnya berupa jasa mendasar untuk konsumsi bersama dalam komunitas (air bersih, sanitasi, transportasi, fasilitas kesehatan, dan fasilitas pendidikan). Masyarakat juga membutuhkan partisipasi masyarakat miskin dalam pengambilan keputusan yang berkaitan dengan diri mereka sendiri. Kebutuhan lainnya berupa kepuasan atas batas minimum kebutuhan dasar di atas, dan perolehan kesempatan kerja

Konteks pembangunan partisipatif pada dekade berikutnya, 1980-an, lebih berupa penguatan peran LSM (Rahnema, 1992). Sejalan dengan penguatan LSM tersebut, terjadilah pengurangan peran negara, terutama dalam pasar dan pembangunan ekonomi. Penurunan peran negara ini dimulai kala negara-negara Amerika Latin dan Afrika terbelit krisis utang luar negeri. Para donor mengembangkan pola penyesuaian struktural untuk meningkatkan peluang negara Amerika Latin dalam membayar utang. Pola ini kemudian diterapkan kepada seluruh negara lain yang sedang mengalami krisis keuangan berkaitan dengan utang luar negeri.

Menanggapi respons donor tersebut, kalangan LSM melakukan koordinasi hingga ke tingkat internasional. Mereka menggalang pemikiran untuk mengutamakan pembangunan partisipatif di tingkat akar rumput. Pada saat inilah pembangunan partisipatif bersinergi dengan pengembangan komunitas.

Pada dekade 1990-an, pembangunan partisipatif juga dikembangkan dalam proyekproyek donor. Metode yang dikenalkan di antaranya CDD (Community-Driven Development) (Dongier, et.al., 2003), yang dikembangkan bersama-sama dengan good governance untuk menurunkan peran negara ke dalam pasar. Peran fasilitasi masyarakat kemudian digantikan oleh swasta, konsultan, atau sebagian LSM.

Orientasi good governance sekaligus menjadi salah satu tanda masuknya pendekatan partisipatif ke dalam birokrasi pemerintahan -bukan sekedar pada proyek-proyek pembangunan. Di Indonesia masuknya aspek partisipatif ke dalam sistem pemerintahan terbuka antara lain melalui UU 17/2003 tentang Keuangan Negara dan UU 25/2004 tentang Sistem Perencanaan Pembangunan Nasional. 


\section{Ragam Paradigma Pembangunan Partisipatif}

\section{Konsistensi di Antara Beragam Paradigma}

Untuk mendapatkan landasan yang kuat dalam membahas pembangunan partisipatif secara konseptual, maka mula-mula dibutuhkan diskusi perihal paradigma. Istilah paradigma mencakup kepercayaan dasar atau "suatu kacamata" dalam memandang suatu perkara (Kuhn, 2002), dalam hal ini pembangunan. Dengan demikian suatu fakta pembangunan yang sama dapat dikembangkan secara berlainan menurut paradigma tersebut.

Pengetahuan tentang beragam paradigma berguna untuk mengetahui pengelompokan cara pandang yang lebih sederhana di antara belantara teori yang ada. Akan semakin berguna pengetahuan ini, manakala ditemukan kaitan antar beragam paradigma yang ada. Pengetahuan tambahan ini memungkinkan ketrampilan dalam menyusun suatu konsep multidisiplin, maupun untuk mengimplementasikan suatu konsep ke dalam praktek yang lebih nyata.

Tabel 1 menunjukkan konsistensi antar beragam paradigma pembangunan, pemberdayaan, pengembangan masyarakat, dan partisipasi. Konsep yang sangat besar berupa "pembangunan" masa kini dapat dipraktekkan ke dalam tindakan "pemberdayaan". Strategi untuk mendampingi masyarakat diterapkan dalam metode "pengembangan masyarakat". Pada titik inilah kemunculan gerak dan interaksi dari masyarakat mewujud dalam "partisipasi".

Tabel 1. Konsistensi Antar Paradigma Pembangunan, Pemberdayaan, Pengembangan Masyarakat, dan Partisipasi

\begin{tabular}{|l|l|l|l|l|}
\hline $\begin{array}{c}\text { Turunan } \\
\text { Pembangunan }\end{array}$ & $\begin{array}{c}\text { Paradigma } \\
\text { Berbasis Manusia } \\
\text { (People- Centered } \\
\text { Development })\end{array}$ & $\begin{array}{c}\text { Paradigma } \\
\text { Neoliberalisme/ } \\
\text { Intervensionisme } \\
\text { Pasar }\end{array}$ & $\begin{array}{c}\text { Paradigma } \\
\text { Intervensionisme } \\
\text { negara }\end{array}$ & $\begin{array}{c}\text { Paradigma } \\
\text { Strukturalisme }\end{array}$ \\
\hline Pemberdayaan & Berbasis manusia & Pluralis & Elitis & Struktural \\
\hline $\begin{array}{l}\text { Pengembangan } \\
\text { Masyarakat } \\
\text { (CD) }\end{array}$ & Berbasis Manusia & Pasar & Negara & LSM \\
\hline Partisipasi & Argumen Proses & Argumen Efisiensi & $\begin{array}{l}\text { Argumen } \\
\text { Efektivitas }\end{array}$ & $\begin{array}{l}\text { Argumen Hak } \\
\text { Orang Miskin }\end{array}$ \\
\hline Proyek Tipikal & IDT & PPK, P2KP & RISP & $\begin{array}{l}\text { Advokasi buruh } \\
\text { PRD }\end{array}$ \\
\hline
\end{tabular}

Keterangan: Kategorisasi diolah dari Ife (1995), Thomas (2002), Cornwall (2000)

Sejalan dengan paradigma pembangunan berbasis manusia (people-centered development), pemberdayaan dijalankan dengan ciri-ciri berbasis manusia (peoplecentered empowerment). Strategi pengembangan masyarakatpun berkembangan melalui ciri-ciri berbasis manusia (people-centered community development). Partisipasi yang muncul dari masyarakat berorientasi kepada proses atau tahapan partisipatoris. Di Indonesia proyek yang memiliki ciri-ciri semacam ini di antaranya Program IDT (Inpres Desa Tertinggal). Ciri khusus dalam proyek ini ialah pengembangan kelompok untuk meningkatkan potensi masyarakat setempat. 
Adapun paradigma pembangunan neoliberal (pembangunan sama dengan kapitalisme), atau minimal pembangunan yang penuh intervensi pasar, lazim mengenakan pemberdayaan pluralis. Strategi pengembangan masyarakatpun berorientasi pasar, yang bercirikan interaksi persaingan. Partisipasi dari masyarakat digali demi meningkatkan efisiensi pembangunan. Di sinilah letak proyek dari kebanyakan donor internasional, misalnya Program Pengembangan Kecamatan (PPK), Program Penanggulangan Kemiskinan di Perkotaan (P2KP).

Intervensi negara dalam pembangunan sejajar dengan pemberdayaan elitis. Upayaupaya untuk menghubungkan masyarakat dan negara dilancarkan melalui strategi pengembangan masyarakat berbasis negara, yang mengelola rumusan hak dan kewajiban warganegara. Partisipasi masyarakat dikembangkan untuk memastikan bahwa usulan kegiatan yang ada secara efektif sesuai dengan realitas kebutuhan warganegara. Di sinilah letak P2SPP yang seharusnya muncul, karena pemerintah hendak menggali kebutuhan dari masyarakat sendiri. Program lain yang memiliki kekhususan dalam paradigma ini ialah Program Pembangunan Infrastruktur Perdesaan (PPIP) atau Rural Infrastructure Support Project (RISP).

Adapun pembangunan bermodel strukturalis mengupayakan pemberdayaan struktural pula. Di sini struktur kelas dalam masyarakat berusaha diubah, di mana kelompok miskin memiliki kedudukan yang sejajar dengan kelas atas. Pengembangan masyarakat ala LSM dilaksanakan untuk mewujudkan hak-hak orang miskin dalam perencanaan, pelaksanaan dan evaluasi pembangunan pada semua level birokrasi. Advokasi kepada buruh untuk menjadi kesamaan akses kepada alat produksi juga merupakan contoh tipikal partisipasi dalam paradigma ini.

Sebenarnya masih ada satu paradigma lagi yang berada di luar konsep pembangunan, dan karena mengupayakan keluar dari pembangunan maka tidak dibahas di sini. Paradigma tersebut biasa dinamai pasca-pembangunan (postdevelopment). Pemikiran pasca-pembangunan tidak lagi menghendaki munculnya proses pembangunan (Escobar, 2005; Esteva, 1992). Peran pembangunan dinilai sekedar omong kosong atau tipuan, yang hanya berguna untuk menguatkan hegemoni Amerika Serikat. Pandangan ini berkaitan dengan peran Amerika Serikat dalam pemberian kredit bagi pembangunan Eropa usai Perang Dunia II, juga pinjaman luar negeri kepada negara-negara di Asia, Afrika dan Amerika Latin. Institusi pembangunan penting juga di bawah pengaruh Amerika Serikat sebagai kompensasi pemasok dana terbesar, yaitu Bank Dunia (World Bank) dan IMF (International Monetary Fund).

\section{Ragam Paradigma Partisipasi}

Pembangunan partisipatif mencakup beberapa aspek berikut (Rahnema, 1992). Pertama, kognitif, dalam rangka mengembangkan pemahaman atas pemikiran yang berbeda dalam memandang realitas sosial dan alamiah sekeliling. Kedua, politik, dalam rangka menguatkan suara-suara dari pihak-pihak yang selama ini terpinggirkan. Ketiga, instrumental, dalam rangka menyusun suatu alternatif baru. Bentuk-bentuk kunci partisipasi mencakup rumahtangga, ekonomi, sosial-kultural, dan politik. Seluruh hal ini saling mempengaruhi satu sama lain. 
Adapun pembahasan yang paling penting dalam pembangunan partisipasi ialah perihal kekuasaan. Upaya meningkatkan partisipasi dari pihak yang terpinggirkan dapat menghasilkan resistensi dari pihak yang sedang berkuasa. Tidaklah berlebihan untuk menunjukkan bahwa partisipasi bersifat konfliktual, bahkan kadang-kadang bersifat fisik, di mana pihak yang tidak memiliki kekuasaan mesti berjuang untuk meningkatkan kontrol atas hidup mereka sendiri.

Pembangunan partisipatif membalik upaya marjinalisasi dan alienasi penduduk miskin. Satu langkah penting yang perlu dilakukan ialah perubahan paradigm pengetahuan. Pembalikan yang dilakukan ialah, dari sebelumnya mendasarkan pengetahuan dari para ahli (expert knowledge), kini menekankan kebutuhan pengetahuan lokal (local knowledge). Dalam sistem pakar modern yang didasarkan pada pendekatan ilmiah, perencana pembangunan menggunakan model normatif dan sasaran pembangunan diperlakukan sebagai pihak yang pasif, konservatif, bahkan tertinggal. Pembangunan partisipatif melakukan hal sebaliknya, yaitu memandang dunia dari sudut pandang pihak-pihak yang terkena pengaruh pembangunan secara langsung. Di antaranya dengan menggunakan metode PRA (Participatory Rural Appraisal) (Chambers, 1993; Kumar, 2002), yang lebih banyak menggunakan teknik-teknik visual dan oral daripada tertulis, karena memandang media tulisan telah terhegemoni oleh pihak-pihak yang berkuasa.

Partisipasi dapat mengandung aspek subversif. Aspek ini dapat mengemuka manakala pertanyaan pokok partisipasi terjawab, terutama berkenaan dengan kelas sosial yang mengelola masyarakat dan sumberdaya yang bisa diaksesnya. Pertanyaan utama dalam pembangunan partisipatif yang perlu dijawab di antaranya mengapa perlu pendampingan untuk meningkatkan partisipasi? (Why is participating being advocated?) Pertanyaan lainnya ialah siapa yang berpartisipasi? (Who is participating ?), kapan mereka berpartisipasi? (When they are participating ?), bagaimana mereka melakukan tindakan partisipatif? (How they are participating?), siapa yang memperoleh keuntungan dari proses partisipasi? (Who benefits from the participatory process?), siapa yang memperoleh keuntungan dari hasil partisipasi? (Who benefits from the outcomes?)

Dalam menjawab segenap pertanyaan di atas, pihak-pihak yang terlibat dalam partisipasi dapat menempuh jalan yang beragam. Akibatnya kini partisipasi memiliki makna yang beragam pula. Pada akhir 1970-an UNRISD mendefinisikan partisipasi sebagai upaya terorganisasi dari kelompok atau gerakan yang semula terpisah lalu untuk meningkatkan kontrol atas sumberdaya dan institusi penyusun aturan. Dalam dekade 1990-an, World Bank (1994) mendefinisikan partisipasi sebagai proses di mana stakeholder mempengaruhi dan membagi kontrol atas inisiatif pembangunan, keputusan, serta sumberdaya yang mempengaruhi mereka. Terlihat bahwa definisi partisipasi oleh World Bank semakin dangkal dan lebih bersifat instrumental. Bandingkan pendangkalan makna sebagaimana terlihat dari "kontrol" menjadi "mempengaruhi" dan "sharing", serta dari lingkup luas "sumberdaya" dan "institusi pengatur" menjadi sekedar "inisiatif pembangunan".

Perbedaan yang kontras antar beragam partisipasi disajikan pada Tabel 2. Kedalaman semakin meningkat dari argumen, efisiensi-biaya, efektivitas, hingga ke hak orang miskin. Berkaitan dengan pembangunan partisipatif, kiranya pandangan negara dan lembaga donor beserta pendukung kapitalisme berada pada terutama 
pada tataran argumen efisiensi-biaya, bahkan sekedar argumen proses. Contohnya pada PPK, P2KP. Sedangkan pengkritik pembangunan mengharapkan partisipasi lebih mendalam sampai ke tingkat argumen hak orang miskin, atau minimal pada argumen efektivitas. Inilah yang hendak dikembangkan dalam P2SPP.

Diurutkan dari yang berat sampai ringan untuk dilaksanakan, maka argumen pembangunan partisipatif dapat dibedakan (Cornwall, 2000; Francis, 2004; Kumar, 2002; Miraftab, 2003; Mohan, 2004; Mosse, 2004), pertama, menurut argumen hak. Dalam argumen ini partisipasi dalam pembangunan dipandang sebagai hak terutama untuk rakyat miskin- dan inheren dalam strategi pembangunan dan pemberdayaan yang berorientasi kepada orang miskin (pro-poor)

Kedua, argumen efektivitas. Di sini partisipasi seluruh pihak yang terlibat (stakeholders) terutama ditujukan untuk meningkatkan akurasi informasi dan relevansi realitas kehidupan yang diputuskan dan dibangun.

Ketiga, argumen efisiensi-biaya. Keikutsertaan pelaku atau pemanfaat utama pembangunan (stakeholders utama) dapat meningkatkan rasa kepemilikan dalam proses pembangunan, penggunaan sumberdaya lebih baik untuk memobilisasi sumberdaya lokal dalam mensubstitusi input dari luar

Keempat, argumen proses: proses partisipasi meningkatkan ketrampilan, kapasitas dan jaringan bagi partisipan sehingga mewujudkan pembangunan yang pro-poor, berbasis civil society dan pemberdayaan

Tabel 2. Ragam Paradigma Partisipasi

\begin{tabular}{|c|c|c|c|}
\hline Bentuk & $\begin{array}{c}\text { Arti "Partisipasi" bagi } \\
\text { Agen Pelaksana }\end{array}$ & $\begin{array}{c}\text { Arti “Partisipasi”' bagi } \\
\text { Penerima }\end{array}$ & $\begin{array}{c}\text { Kegunaan } \\
\text { "Partisipasi" }\end{array}$ \\
\hline $\begin{array}{l}\text { Nominal } \\
\text { (Argumen } \\
\text { Proses) }\end{array}$ & $\begin{array}{l}\text { Legitimasi: untuk } \\
\text { menunjukkan bahwa } \\
\text { mereka telah melakukan } \\
\text { sesuatu }\end{array}$ & $\begin{array}{l}\text { Keikutsertaan: membuka } \\
\text { akses atas manfaat } \\
\text { potensial }\end{array}$ & Displai \\
\hline $\begin{array}{l}\text { Instrumental } \\
\text { (Argumen } \\
\text { Efisiensi- } \\
\text { Biaya) }\end{array}$ & $\begin{array}{l}\text { Efisiensi: untuk membatasi } \\
\text { biaya input, menggali } \\
\text { kontribusi komunitas, dan } \\
\text { menyusun proyek yang } \\
\text { efektif dari sisi biaya }\end{array}$ & $\begin{array}{l}\text { Biaya: atas waktu yang } \\
\text { digunakan dalam } \\
\text { pengerjaan proyek dan } \\
\text { kegiatan lain }\end{array}$ & $\begin{array}{l}\text { Sebagai alat untuk } \\
\text { mencapai } \\
\text { efektivitas biaya } \\
\text { dan fasilitas lokal }\end{array}$ \\
\hline $\begin{array}{l}\text { Representatif } \\
\text { (Argumen } \\
\text { Efektivitas }\end{array}$ & $\begin{array}{l}\text { Keberlanjutan: } \\
\text { menghilangkan } \\
\text { ketergantungan }\end{array}$ & $\begin{array}{l}\text { Peningkatan status: } \\
\text { mempengaruhi bentuk } \\
\text { dan manajemen proyek }\end{array}$ & $\begin{array}{l}\text { Memberikan suara } \\
\text { bagi masyarakat } \\
\text { dalam } \\
\text { mengarahkan } \\
\text { pembangunan } \\
\text { mereka sendiri }\end{array}$ \\
\hline $\begin{array}{l}\text { Transformatif } \\
\text { (Argumen } \\
\text { Hak Orang } \\
\text { Miskin) }\end{array}$ & $\begin{array}{l}\text { Pemberdayaan: } \\
\text { menguatkan kapabilitas } \\
\text { masyarakat untuk } \\
\text { memutuskan dan bertindak } \\
\text { bagi diri mereka sendiri }\end{array}$ & $\begin{array}{l}\text { Pemberdayaan: } \\
\text { kemampuan } \\
\text { memutuskan dan } \\
\text { bertindak bagi diri } \\
\text { mereka sendiri }\end{array}$ & $\begin{array}{l}\text { Sebagai alat dan } \\
\text { tujuan yang } \\
\text { senantiasa dinamis }\end{array}$ \\
\hline
\end{tabular}

Sumber: Dikembangkan dari Cornwall (2000) 
Sesuai dengan ragam argumen di atas, maka tujuan akhir pembangunan partisipatif dapat disusun secara beragam. Berbasis argumen hak, tujuan akhir untuk memastikan kelompok yang paling miskin memperoleh manfaat terbesar dalam proses partisipatif Argumen efektivitas memastikan pembangunan mampu menanggulangi permasalahan lokal atau meningkatkan potensinya. Argumen efisiensi-biaya memastikan pembangunan semakin murah karena efisiensi meningkat dan biaya semakin rendah. Adapun argumen proses memastikan peningkatan ketrampilan, kapasitas dan jaringan warga komunitas dalam pembangunan

Meskipun pembangunan partisipatif memiliki aura positif, namun pelaksanaannya selama ini sempat mengundang kritik pula. Istilah pembangunan partisipatif menjadi klise (Cooke dan Kothari, 2001; Rahnema, 1992). Sejak istilah pembangunan partisipatif menjadi populer dalam digunakan oleh banyak agensi pembangunan, isinya justru semakin jauh dari upaya pemberdayaan. Sebagian organisasi menggunakan istilah ini hanya muntuk mendapatkan legitimasi dalam perolehan dana. PRA (participatory rural appraisal) yang semula dilakukan untuk mengkritik elitisme pembangunan, kini setelah banyak digunakan agensi pembangunan hanya bersifat sebagai stempel dari pihak di luar penduduk lokal.

Kritik lainnya diarahkan karena sebagian besar kegiatan pembangunan partisipatif memandang komunitas secara homogen, sekalipun beberapa hasil PRA yang lebih sensitif menemukan heterogenitas dalam komunitas (Mosse, 2001). Aspek penting heterogenitas komunitas ialah dalam hal gender dan stratifikasi sosial. Sementara kegiatan pemberdayaan biasanya melewati birokratisme pemerintah, namun dengan menyalurkan bantuan melalui elite sebenarnya kegiatan itu juga sedang memarjinalisasi lapisan bawah ke sisi.

Kritik lainnya pada tingkat organisasi (Mohan, 2001; Mosse, 2001). Pembentukan atau penguatan suatu kelompok masyarakat madani baru dan tertentu, ternyata dapat menghasilkan persaingan dengan organisasi lokal. Oleh karena donor biasanya menyalurkan sumberdaya melalui kelompok yang memiliki organisasi lebih baik, maka pembangunan partisipatif justru melemahkan kelompok lokal.

Sesungguhnya persoalan yang ada lebih besar daripada sifat lokalitas, dan senantiasanya berimplikasi kepada ketergantungan. Jika pembangunan partisipatif selama ini memberikan kontrol kepada penduduk lokal, seringkali dilupakan bahwa banyak pengaruh lain dalam kehidupan mereka berada di atas level lokalitas tersebut. Masih sulit untuk membayangkan transformasi perdesaan di negara sedang berkembang, sementara ekonomi nasional masih dikuasai oleh WTO (World Trade Organization) (Francis, 2001).

\section{Legalitas bagi Pembangunan Partisipatif}

\section{Dua Sub Struktur Penjaga Efektivitas Kebijakan}

Sebagaimana kaidah bahwa wewenang yang efektif senantiasa dibekali dengan kekuasaan, ternyata pola efektivitas kebijakan pembangunan (wewenang) juga selalu diiringi dengan alokasi sumberdaya (kekuasaan) baik berupa barang, natura, maupun dana (Cabannes, 2004). Dalam konteks hubungan antara negara dan rakyat, maka kedua sub struktur tersebut dimaknai sebagai kewajiban atau tugas di satu sisi, dan hak pada sisi lainnya. Peraturan perundangan yang dikeluarkan akhir-akhir ini 
mengandung kedua sub struktur tersebut. Hal ini terwujud dalam satu atau lebih peraturan perundangan, namun selalu disebut sebagai satu kesatuan. Misalnya UU 22/1999 menyatu dengan UU 25/1999, begitu pula perubahannya pada UU 32/2004 dan UU 33/2004. Di dalam struktur organisasi departemen, kedua struktur ini dijadikan alam pengendalian program, misalnya menyatukan fungsi perencanaan dengan penganggaran. Di pihak lain, kebijakan partisipasi yang hanya memuat kewajiban (untuk menjalankan mekanisme atau tahapan partisipasi) tanpa memuat sub struktur hak, ternyata tidak berjalan lama di lapangan. Dalam konteks serupa, program-program pemberdayaan yang berhasil dijalankan juga mengandung sub struktur tugas (tahapan atau mekanisme pemberdayaan) dan hak (dana, material, pendampingan).

Dari bahasan di atas dapat dinyatakan dua sub-struktur pembangunan yang efektif di Indonesia, pertama, struktur kewajiban, yaitu struktur dan pembagian wewenang tugas, fungsi, dan kewajiban antar level pemerintahan dari tingkat pusat, propinsi, kabupaten, kecamatan, hingga desa. Kedua, struktur hak, yaitu struktur dan pembagian wewenang keuangan antar level pemerintahan dari tingkat pusat, propinsi, kabupaten, kecamatan, hingga desa.

Pembagian dua jenis sub struktur tersebut bermakna untuk menjaga efektivitas kebijakan di lapangan. Program PPK dan P2SPP dipandang lebih efektif dijalankan dibandingkan mekanisme perencanaan reguler pada saat ini. Alasan yang kuat karena seluruh kegiatan maupun dana kegiatan untuk kedua program ini dapat diperoleh masyarakat langsung dalam satu tahun anggaran yang sama. Dibandingkan dengan hal tersebut, kegiatan yang dimasukkan ke dalam perencanaan pembangunan reguler baru mencakup kewajiban pelaksanaan Musyawarah Perencanaan Pembangunan (musrenbang) bagi masyarakat pada suatu tahun anggaran, namun tidak ada hak yang nyata bagi masyarakat untuk mendapatkannya pada tahun anggaran berikutnya.

\section{Kebijakan Tanpa Orang Miskin}

Dalam UU 25/2004 tentang Sistem Perencanaan Pembangunan Nasional, wilayah kerja perencanaan dimulai dari penyusunan rencana, penetapannya, hingga pengendalian rencana dan evaluasinya. Dibandingkan dengan pola manajemen berupa perencanaan, pelaksanaan dan kontrol, maka paralelisme muncul pada keduanya (Tabel 3). Dengan kata lain, pola perencanaan nasional yang diketengahkan hendak mencakup pula pola pembangunan nasional.

Tabel 3. Paralelisme Manajemen Perencanaan dan Pembangunan Nasional

\begin{tabular}{|l|l|}
\hline \multicolumn{1}{|c|}{ Tahapan Manajemen } & \multicolumn{1}{c|}{ Tahapan Perencanaan Nasional } \\
\hline \multirow{2}{*}{ Perencanaan } & Perencanaan \\
\cline { 2 - 2 } & Penetapan \\
\hline Pelaksanaan & Pengendalian Pelaksanaan \\
\hline Kontrol & Evaluasi Pelaksanaan \\
\hline
\end{tabular}

Pola-pola pembangunan nasional yang diadopsi mencakup (Tabel 4), pertama, pendekatan politis, memandang bahwa pemilihan Presiden/Kepala Daerah adalah proses penyusunan rencana, karena rakyat pemilih menentukan pilihannya berdasarkan program-program pembangunan yang ditawarkan masing-masing calon 
Presiden/Kepala Daerah. Oleh karena itu, rencana pembangunan adalah penjabaran dari agenda-agenda pembangunan yang ditawarkan Presiden/Kepala Daerah pada saat kampanye ke dalam rencana pembangunan jangka menengah

Kedua, pendekatan teknokratis, dilaksanakan dengan menggunakan metode dan kerangka berpikir ilmiah oleh lembaga atau satuan kerja yang secara fungsional bertugas untuk itu.

Ketiga, pendekatan partisipatif dilaksanakan dengan melibatkan semua pihak yang berkepentingan (stakeholders) terhadap pembangunan. Pelibatan mereka adalah untuk mendapatkan aspirasi dan menciptakan rasa memiliki.

Keempat, pendekatan atas-bawah (top-down) dan bawah-atas (bottom-up) dalam perencanaan dilaksanakan menurut jenjang pemerintahan. Rencana hasil proses atasbawah dan bawah-atas diselaraskan melalui musyawarah yang dilaksanakan baik di tingkat Nasional, Provinsi, Kabupaten/Kota, Kecamatan, dan Desa.

Tabel 4. Pelaku Utama dan Argumen Partisipasi dalam Keragaman Pola Pembangunan Nasional

\begin{tabular}{|c|c|c|c|c|}
\hline $\begin{array}{c}\text { Pola } \\
\text { Pembangunan }\end{array}$ & $\begin{array}{c}\text { Pelaku Utama } \\
\text { yang } \\
\text { Diharapkan }\end{array}$ & $\begin{array}{c}\text { Tipikal } \\
\text { Argumen } \\
\text { Partisipasi }\end{array}$ & $\begin{array}{c}\text { Tipikal Ranah } \\
\text { Pembangunan } \\
\text { menurut UU } \\
25 / 2004\end{array}$ & $\begin{array}{c}\text { Peluang Perbaikan } \\
\text { Partisipasi }\end{array}$ \\
\hline Partisipatif & DOUM: rakyat & $\begin{array}{l}\text { Hak orang } \\
\text { miskin }\end{array}$ & $\begin{array}{l}\text { Penggalian } \\
\text { gagasan, } \\
\text { musrenbang } \\
\text { desa dan } \\
\text { kecamatan } \\
\end{array}$ & $\begin{array}{l}\text { Penggalian gagasan, } \\
\text { wakil orang miskin } \\
\text { dan perempuan di } \\
\text { tingkat desa sampai } \\
\text { nasional }\end{array}$ \\
\hline Politis & $\begin{array}{l}\text { Pejabat } \\
\text { politis/politikus: } \\
\text { presiden, kepala } \\
\text { daerah, kepala } \\
\text { desa }\end{array}$ & Efektivitas & Visi dan misi & $\begin{array}{l}\text { Visi dan misi tentang } \\
\text { peliuang bekerja dan } \\
\text { berusaha; revisi visi } \\
\text { dan misi selama } \\
\text { periode menjabat } \\
\text { sesuai perubahan } \\
\text { kebutuhan } \\
\text { masyarakat }\end{array}$ \\
\hline Teknokratis & $\begin{array}{l}\text { Pengampu ilmu } \\
\text { pengetahuan: } \\
\text { tenaga ahli, } \\
\text { akademisi, } \\
\text { konsultan, } \\
\text { swasta }\end{array}$ & $\begin{array}{l}\text { Efisiensi- } \\
\text { biaya }\end{array}$ & $\begin{array}{l}\text { Penyusunan } \\
\text { rencana } \\
\text { pembangunan } \\
\text { tahunan, jangka } \\
\text { menengah, } \\
\text { jangka panjang, } \\
\text { RKA }\end{array}$ & $\begin{array}{l}\text { Rencana } \\
\text { peningkatan peluang } \\
\text { kerja dan usaha; } \\
\text { turut serta atau } \\
\text { menggunakan } \\
\text { dokumen penggalian } \\
\text { gagasan dari desa } \\
\text { hingga nasional }\end{array}$ \\
\hline $\begin{array}{l}\text { Top-down dan } \\
\text { bottom-up }\end{array}$ & $\begin{array}{l}\text { Birokrasi: aparat } \\
\text { pemerintah } \\
\text { pusat, propinsi, } \\
\text { kabupaten/kota, } \\
\text { kecamatan, } \\
\text { desa/kelurahan }\end{array}$ & Proses & $\begin{array}{l}\text { Pelaksanaan } \\
\text { Musrenbang } \\
\text { dan } \\
\text { pelaksanaan } \\
\text { pembangunan }\end{array}$ & $\begin{array}{l}\text { Musrenbang sebagai } \\
\text { satu-satunya basis } \\
\text { penyusunan } \\
\text { anggaran } \\
\text { pembangunan dalam } \\
\text { APBD/N; penguatan } \\
\text { musrenbang }\end{array}$ \\
\hline
\end{tabular}


Sesungguhnya terdapat kerancuan konseptual dalam pembagian di atas, di mana topdown dan bottom-up masuk dalam paradigma yang sama. Sesungguhnya top-down mengandaikan kepandaian lapisan atas (atau teknokrat) sementara bottom up mengandaikan kepakaran lapisan bawah (atau partisipatif).

Alur proses perencanaan dimulai dari atas, bukan dari bawah. Hal ini menjauhkan partisipasi, terutama yang berasal dari kebutuhan lapisan bawah (community-driven) misalnya dalam konsep CDD.

UU Perencanaan Nasional tersebut juga tidak menggunakan argumen hak orang miskin. Hak kelompok terpinggirkan yang diakomodasi ialah perempuan, namun representasi merekapun terbatas sampai level propinsi. Di samping itu, yang diharapkan bukan perempuan dari kelompok miskin, melainkan tokoh perempuan. Sektor masyarakat yang menjadi salah satu penopang negara modern, ternyata juga hanya dimaknai sebagai elite di luar pemerintah, yaitu asosiasi profesi, perguruan tinggi, lembaga swadaya masyarakat, pemuka adat dan pemuka agama, serta kalangan dunia usaha. Tidak ada golongan miskin dan perempuan dalam definisi masyarakat tersebut.

Pola partisipatif yang diharapkan dalam undang-undang ini sebetulnya masuk ke dalam argumen proses, yang berupa upaya kolaborasi diantara pihak-pihak yang melaksanakan pembangunan. Namun demikian, dalam rancangan evaluasi pembangunan terlewat aspek kekuasaan dalam proses atau tahapan partisipatif tersebut. Evaluasi hanya diarahkan kepada masukan (input), keluaran (output), hasil (result), manfaat (benefit) dan dampak (impact). Di pihak lain, pengalaman proyekproyek partisipatif selama ini menunjukkan bahwa proses atau tahapan partisipatif seringkali menciptakan tokoh bagi pengelola proses tersebut. Di antara tokoh ini ada yang selanjutnya menjadi anggota legislatif maupun eksekutif. Menyadari hal ini, evaluasi hendaknya mencakup pula aspek proses atau tahapan partisipatif.

Isi pembangunan yang bersifat politis tertuju kepada politikus yang mendudukan jabatan pemerintahan. Untuk menjalankan perannya, politikus perlu menyamakan visi dan misinya dengan milik rakyat. Evaluasi rakyat lebih banyak tertuju kepada kemampuan program pembanguunan untuk memenuhi kebutuhan masyarakat. Konsekuensinya pembangunan partisipatif yang patut dikembangkan di sini tampaknya berada dalam argumen efektivitas.

Para teknokrat, akademisi dan pakar memiliki wewenang untuk menyusun rencana pembangunan jangka panjang, menengah, hingga tahunan. Upaya penyusunan dokumen perencanaan ini mengandung aspek kekuasaan penyusunnya. Untuk mencapai pembangunan partisipatif, maka seharusnya penyusunan rencana pembangunan didasarkan pada kebutuhan rakyat, atau jika memungkinkan maka perencana turut menyusun hal ini bersama rakyat.

Adapun birokrat mengembangkan proses partisipasi dalam segenap mekanisme perencanaan dan pelaksanaan pembangunan secara berjenjang. Satu-satunya lembaga yang ditujukan untuk mempertemukan semua pihak dalam proses pembangunan ialah musrenbang. Oleh karena ini menjadi lembaga demokratis utama, maka musrenbang perlu dikuatkan melalui pelaksana yang memahami tahapan dan teknik pengelolaan partisipatoris. Idealnya musrenbang menjadi satu- 
satunya lembaga untuk menyusun anggaran pembangunan atau aspek kegiatan dalam APBD atau APBN, atau berarti menutup peluang lobi politik di luar musrenbang.

Skema penyusunan Anggaran Pendapatan dan Belanja Daerah (APBD) dimulai dari penyusunan arah dan kebijakan umum APBD. Dari sini disusun lebih jauh strategi dan prioritas APBD (Gambar 1). Di dalamnya tercakup visi, misi, tupoksi, tujuan dan sasaran unit kerja. Ada pula program dan kegiatan unit kerja. Hal lainnya ialah rancangan anggaran unit kerja.

Hasil dokumen di atas kemudian menjadi rancangan APBD. Tahapan penyusunan RAPBD dapat dimulai dari Musyawarah Perencanaan Pembangunan (Musrenbang) di tingkat desa atau kelurahan. Forum ini dilaksanakan pada bulan Januari. Hal-hal yang didiskusikan mencakup daftar prioritas masalah dan potensi desa, RPJM desa, disertai informasi dari aparat Kabupaten tentang perkiraan dana alokasi desa atau kelurahan, serta isu strategis kabupaten atau kota.

Pada bulan Pebruari dilaksanakan Musrenbang kecamatan. Di sana disusun daftar usulan kegiatan pengembangan wilayah kecamatan, serta wakil kecamatan tersebut dalam Musrenbang kabupaten. Hal-hal lain yang didiskusikan ialah prioritas kebutuhan desa, disertai informasi dari aparat Kabupaten tentang isu strategis kabupaten atau kota.

Pada bulan Maret dilaksanakan sekaligus pra-Musrenbang Kabupaten/Kota, pelaksanaan Musrenbangda, dan pasca Musrenbangda. Di sana didiskusikan prioritas bidang, daftar program dan kegiatan prioritas yang didanai oleh APBD, serta usulan kebijakan dan regulasi pada tingkat pemerintah kabupaten/kota, propinsi, dan nasional. Dibicarakan pula rancangan dana alokasi desa.

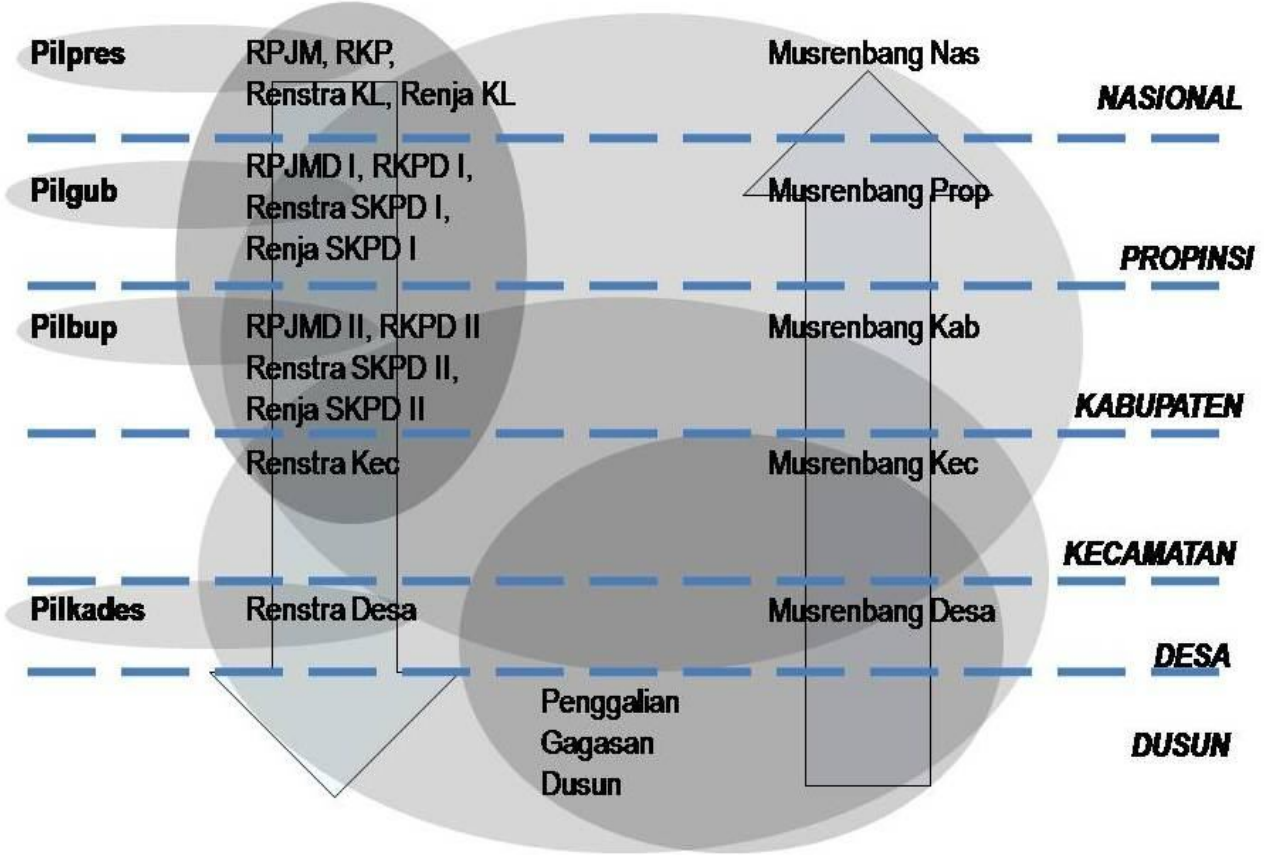


Pada bulan April diselenggaran Musrenbang Propinsi. Didiskusikan Repetada, serta usulan pembiayaan dari APBN. Akhirnya diselenggarakan Musrenbang Nasional. Di dalamnya diserasikan aspirasi dari daerah dengan kebutuhan pembangunan nasional. Disetujui pula anggaran pembangunan di tingkat nasional.

\section{Kasus P2SPP}

\section{Desain Program}

Program Pengembangan Sistem Pembangunan Partisipatif (P2SPP) merupakan upaya mengentaskan kemiskinan dan pemberdayaan masyarakat dengan mengembangkan mekanime dan sistem pengajuan usulan mulai dari Pokmas, Dusun, Musrenbangdes/kel, Musrenbangkec, dan Musrenbang kabupaten untuk menjadi prioritas pembangunan daerah. P2SPP merupakan salah satu pilot project dari Program Pengembangan Kecamatan (PPK). Adapun PPK telah mengenalkan sistem pembangunan partisipatif mulai dari tingkat kelompok masyarakat sampai tingkat kecamatan. Sampai di sini skema berbasis pada peningkatan kesejahteraan perdesaan di tingkat kecamatan perlu lebih ditingkatkan, melalui skema pembangunan di tingkat kabupaten. Oleh sebab itu pelaksanaan pilot project $\mathrm{P} 2 \mathrm{SPP}$ juga juga melibatkan kecamatan lokasi PPK dan di luar lokasi PPK.

Sementara PPK semula merupakan inisiatif bersama pemerintan Indonesia dan negara donor, maka P2SPP sepenuhnya berasal dari inisiatif pemerintah Indonesia. Tujuan PPK semata-mata dibatasi pada pendekatan keproyekan, sementara P2SPP mengarahkan perubahan dari pendekatan proyek kepada penedekatan birokrasi reguler. Penyusunan Petunjuk Teknis Operasional (PTO) dalam PPK dilaksanakan secara terpusat dan berlaku sama untuk seluruh wilayah Indonesia, sementara PTO dalam P2SPP disusun dengan memperhatikan konteks lokal yang beragam. Oleh karena lebih dikelola oleh pemerintah daerah, dan disesuaikan dengan periode perencanan pembangunan, maka periode perencanaan dan pelaksanaan P2SPP hanya 12 bulan. Sementara itu pada PPK kegiatan ini berlangsung selama lebih dari setahun. Pola pengaliran dana P2SPP diarahkan ke tingkat kabupaten dan kecamatan, sedangkan PPK mengalir hanya ke kecamatan. Sejalan dengan itu fasilitator dalam P2SPP ditambah dibandingkan PPK, dinamai setrawan dan berasal dari pegawai pemerintah daerah. Terlihat di sini pemerintah daerah lebih antusias dan terlibat lebih mendalam dibandingkan PPK. Namun demikian pemerintah daerah masih memiliki kesulitan untuk menyediaan alokasi dana dari APBD. Masalah lainnya ialah kesenjangan antara pendekatan keproyekan dan pendekatan pembangunan reguler, kesulitan untuk mengintegrasikan kegiatan masyarakat dan pemerintah daerah, serta kesulitan memadukan aturan pelibatan kepala desa atau tim pengelola kegiatan PPK di tingkat desa.

Tujuan umum P2SPP adalah untuk mengintegrasikan pengalaman manajemen pembangunan yang partisipatif ke dalam manajemen pembangunan daerah. Sasaran yang akan dicapai dalam P2SPP adalah terintegrasinya mekanisme perencanaan yang partisipatif ke dalam perencanaan pembangunan daerah (Musrenbang Desa/Kelurahan, Musrenbang Kecamatan, dan Musrenbang Kabupaten). Sasaran lainnya berupa terintegrasinya pendampingan masyarakat dan pemerintah lokal ke dalam fungsi pemerintahan (setrawan), terintegrasinya model Bantuan Langsung Masyarakat (BLM) ke dalam sistem penganggaran pemerintah kabupaten dan desa, 
terintegrasinya model swakelola masyarakat dalam pelaksanaan pembangunan perdesaan ke dalam manajemen pelaksanaan pembangunan daerah dan desa. Sasaran berikutnya ialah meningkatnya kemampuan pengambil kebijakan (perencanaan, penganggaran, regulasi, pelayanan sosial dasar di kabupaten dalam mengartikulasikan aspirasi masyarakat dan mengelola potensi lokal. Kelompok Sasaran dalam P2SPP meliputi masyarakat miskin di desa/kelurahan, Kelembagaan masyarakat di desa/kelurahan, dan kelembagaan pemerintahan lokal.

Untuk menjalankan tujuan dan sasaran di atas, maka Program Pengembangan Sistem Pembangunan Partisipatif (P2SPP) memberikan bantuan kepada masyarakatdalam satu kabupaten dalam bentuk, pertama, keswadayaan masyarakat. Keswadayaan masyarakat merupakan bentuk partisipasi masyarakat dengan melihat potensi lokal yang diwujudkan baik dalam bentuk barang, tenaga, pikiran, jasa, dan waktu.

Kedua, Bantuan Langsung Masyarakat. Bantuan langsung kepada masyarakat berupa dana yang akan dipergunakan oleh masyarakat dalam menyelenggarakan kegiatan pembangunan sarana prasarana sosial dasar dan ekonomi. Bantuan ini diperuntukkan kepada masyarakat di kecamatan, terutama dimanfaatkan oleh penduduk miskin.

Ketiga, dunia usaha. Dunia usaha diharapkan dapat terlibat sebagai wujud kepedulian terhadap masyarakat mengingat partisipasi dunia usaha dalam pemberdayaan masyarakat. Keterlibatan dunia usaha dapat diwujudakan dalam proses pembiayaan, peningkatan kemampuan masyarakat, dan program-program kegiatan. Dengan demikian terjadi hubungan yang saling menguntungkan antara dunia usaha, pemerintah daerah, dan masyarakat. Keterlibatan dunia usaha harus berkoordinasi dengan pemerintah daerah, dan masyarakat.

Keempat, berupa Bantuan Teknis Pendampingan. Bantuan teknis diberikan pada aparat pemerintah daerah, aparat pemerintahan desa/kelurahan, dan review perda. Disamping itu, peran-peran pendampingan yang akan ditransformasikan kepada pendamping lokal, aparat pemerintah, dan institusi local perlu mendapatkan peniningkatan kemampuan melalui skema pelatihan yang dikembangkan di lokasi pilot. Pendampingan tersebut mulai dari tingkat pusat, propinsi, kabupaten, kecamatan, desa, hingga komunitas. Bantuan teknis pendampingan ini dapat berupa bantuan peningkatan kapasitas baik yang diterima oleh masyarakat maupun pemerintah terutama desa, kecamatan, dan kabupaten agar dapat berinteraksi untuk melembagakan pengelolaan pembangunan daerah yang partisipatif.

Bentuk kegiatan P2SPP disesuaikan dengan need assesment masyarakat dalam menanggulangi kemiskinan. Secara umum hal ini dikelompokkan dalam 3 (tiga) macam, pertama, bantuan kecamatan langsung yang terdiri dari penyediaan, pengembangan dan pemeliharaan sarana/prasarana sosial dasar dan ekonomi. Kedua, fasilitasi pengembangan microfinance di perdesaan, antar lain berupa peningkatan kapasitas keuangan tingkat kecamatan dan kelompok untuk mengelola kegiatan microfinance. Ketiga, pengembangan masyarakat dan pemerintah lokal, kegiatan ini meliputi fasilitasi : (i) Peningkatan kemampuan aparat pemerintahan desa; (ii) Peningkatan kemampuan aparat pemerintah Daerah; dan (iii) Fasilitasi review peraturan daaerah terkait dengan produk hukum yang berkaitan dengan pembangunan perdesaan, dan pembangunan partisipatif. 


\section{Perbandingan antar Kabupaten}

Di daerah pada masa kini muncul teladan perihal meningkatnya hubungan antara pemerintah daerah dan masyarakat. Suatu perkembangan baru menunjukkan dukungan pemerintah daerah terhadap pemberdayaan masyarakat. Hal ini dilaksanakan melalui pengembangan mekanisme pertemuan langsung bupati/wakil bupati dan rakyat. Pertemuan ini dilaksanakan seminggu sampai sebulan sekali. Meskipun pertemuan ini bernilai simbolis, namun efektif bagi pejabat di daerah untuk menggali gagasan langsung dari masyarakat. Sejalan dengan pertemuan tersebut, ada pula pelembagaan pengiriman layanan pesan singkat (SMS) langsung kepada kepala daerah. Revoluisi telekomunikasi ini memungkinkan hubungan langsung dan efektif antara pemerintah daerah dan masyarakat.

Di samping itu, dokumen pembangunan daerah mulai mencantumkan orientasi pemberdayaan masyarakat sebagai pokok pembangunan. Tindakan semcam ini memungkinkan pola pengarusutamaan pemberdayaan masyarakat bagi seluruh program di daerah yang bersangkutan.

Melalui kegiatan-kegiatan di atas, secara terbuka pemerintah daerah menyatakan kebutuhannya untuk memastikan efektivitas penggalian gagasan langsung dari masyarakat. Kebutuhan akan efektivitas penggalian gagasan ini menemukan salurannya dalam mekanisme penggalian gagasan secara partisipatif dalam P2SPP. Oleh sebab itu pemerintah daerah dan sebagian anggota Dewan Perwakilan Rakyat Daerah (DPRD) berminat akan kelancaran kerja P2SPP.

Namun demikian, muncul kelemahan pelaksanaan program dalam hal kapasitas setrawan (aparat pemerintah daerah yang menjadi pendamping) sebagai pihak pemerintah daerah yang seharusnya menyajikan pendampingan kepada warga masyarakat. Kondisi setrawan menunjukkan umumnya tidak aktif atau tidak mampu mendampingi warga masyarakat secara langsung. Alasan yang disampaikan dimulai dari jumlah honor yang dipandang terlalu rendah, ketiadaan waktu kerja karena masih dituntut oleh pekerjaan yang bersifat struktural di samping pemberdayaan masyarakat, belum terbiasa untuk bekerja di luar jam kerja baik pada sore dan malam hari maupun pada hari libur, hingga ketiadaan pengetahuan yang memadai untuk mengelola pendapat dari masyarakat. Dalam kondisi semacam ini, para pendamping PPK di tingkat kabupaten dan kecamatan turut mendampingi setrawan itu sendiri. Kelemahan setrawan ini muncul pada seluruh setrawan di tingkat kecamatan, dan hampir seluruh setrawan di tingkat kabupaten.

Salah satu masalah pokok setrawan ialah ketiadaan "bayangan" (imajinasi) akan karier dan kelangsungan pekerjaan. Setrawan dipandang sebagai suatu jabatan fungsional. Melalui pemikiran semacam ini, setrawan di tingkat kecamatan seringkali ditunjuk dari kelompok fungsional pula, misalnya guru dan pekerja lapangan dari suatu dinas di pemerintah daerah. Akan tetapi pola penjenjangan karier birokratis dalam jabatan fungsional ini tidak ada. Selain itu, dalam pola P2SPP saat ini, yang masih berwujud dalam bentuk keproyekan, posisi setrawan dipandang sebagaimana tambahan pekerjaan sampingan sebagaimana pengelola proyek. 
Dibandingkan dengan jabatan struktural, ternyata jabatan fungsional dalam birokrasi pemerintah daerah dipandang lebih rendah. Setrawan selalu diduduki oleh eselon rendah. Manakala mendapatkan kenaikan jabatan, setrawan tersebut cenderung melepaskan posisinya untuk meraih jabatan struktural yang lebih tinggi. Mutasi yang berupa peningkatan jabatan tersebut menjadikannya keluar dari pola pengelolaan PPK. Akibatnya pejabat baru yang mengelola program pemberdayaan kemudian membutuhkan tambahan waktu lagi agar mampu meningkatkan pengelolaan kegiatan.

Namun demikian, ada pula setrawan di tingkat kabupaten yang memiliki kemampuan dan ketrampilan yang tinggi, yang ditemukan pada Kabupaten Batanghari (Jambi) dan Ngada (Nusa Tenggara Timur). Keaktifan setrawan ini ditunjukkan oleh kemandiriannya dalam mengelola lapangan di tingkat kabupaten, serta kemandiriannya dalam mengelola dokumen atau arsip kegiatan P2SPP. Di lapangan setrawan mampu mengelola konflik lokal atau memberikan saran langsung manakala muncul masalah teknis.

Sebagaimana disajikan pada laporan yang lain, PPK mengandung argumen efisiensibiaya, di mana program dijalankan dengan mekanisme partisipatif terutama untuk meningkatkan efisiensi. Hal ini terwujud dari perbandingan antara nilai input dan output masing-masing kegiatan. Contohnya ditunjukkan dengan menyebutkan peningkatan ruas jalan riil dibandingan dengan rencana. Sebagai salah satu pilot project PPK, ternyata P2SPP juga dijalankan dengan argumen serupa (Tabel 5).

Tabel 5. Perbandingan Argumen Partisipasi dalam P2SPP

\begin{tabular}{|l|l|l|l|l|}
\hline Lokasi & Proses & Efisiensi-Biaya & Efektivitas & Hak \\
\hline $\begin{array}{l}\text { Minahasa } \\
\text { Selatan }\end{array}$ & & & & \\
\hline Ngada & & & \\
\hline Batanghari & & & \\
\hline Boyolali & & & \\
\hline
\end{tabular}

Di samping argumen efisiensi-biaya, ternyata argumen proses juga dijalankan dalam P2SPP. Dalam sejarah program pemberdayaan di Indonesia, sesungguhnya argumen ini sudah muncul sejak program IDT. Argumen proses meminta agar tahapan (yang biasanya dipandang berpanjang-panjang) dalam program partisipatif dilaksanakan secara konsisten. Mekanisme partisipatif dimulai dari perencanaan partisipatif di tingkat dusun hingga kabupaten, kemudian diikuti dengan pelaksanaan secara partisipatif pula oleh masyarakat. Kerangka partisipasi yang sudah dikenal ialah DOUM (dari, oleh, dan untuk masyarakat).

Perbedaan baru muncul dalam pengembangan argumen efektivitas. Dalam argumen ini partisipasi masyarakat dalam program pembangunan dipandang sebagai salah satu jalan untuk memastikan bahwa usulan kegiatan memang sesuai dengan kebutuhan masyarakat. Pandangan akan argumen efektivitas melalui P2SPP sangat penting untuk mengalihkannya dari potensi keproyekan menjadi potensi proses pembangunan secara reguler. Sayang argumen ini tidak muncul di Minahasa Selatan. 
Akan tetapi argumen tentang hak orang miskin belum sempat muncul dalam pelaksanaan P2SPP. Meskipun disadari bahwa pembangunan dirancang untuk menanggulangi kemiskinan, namun posisi orang miskin tidak diberi porsi yang khusus untuk memungkinkan hak mereka terpenuhi. Tidak ada kewajiban untuk menunjukkan orang miskin mewakili dirinya sendiri dalam pertemuan antar desa di tingkat kecamatan maupun kabupaten. Tidak ada pula keharusan untuk memastikan orang miskin berbicara dalam pertemuan sejak di tingkat dusun (dalam bentuk suatu usulan dari orang miskin).

Secara lebih detil, perbandingan pelaksanaan P2SPP disajikan pada Tabel 6. P2SPP seluruhnya diletakkan pada wilayah di mana pemerintah daerah setempat memiliki antusiasme kepada pembangunan partisipatif. Antusiasme tersebut terlihat dari hubungan yang erat antara aparat di tingkat Pusat dan Daerah. Di samping itu, yang terutama antusiasme ini ditunjukkan secara struktural melalui kerelaan pemerintah daerah yang bersangkutan untuk menyertakan dana pendamping bagi pelaksanaan P2SPP.

Mengambil pelajaran dari pelaksanaan PPK, hubungan di daerah antara pemerintah daerah dan pendamping juga menjadi penting. Di lapangan, hubungan erat terjadi antara bagian pemberdayaan masyarakat (Dinas atau Badan Pemberdayaan Masyarakat). Hubungan erat tersebut membentuk modal sosial, yang ditunjukkan oleh hubungan formal sekaligus hubungan informal. Informalitas dibutuhkan dalam program-program pemberdayaan yang membutuhkan fleksibilitas tinggi di lapangan. Fleksibilitas ini tidak akan ditunjang melalui peraturan formal belaka. Hubungan informal ini ditunjukkan melalui komunikasi di luar jam kerja maupun komunikasi secara langsung tanpa melalui protokoler birokratis. 
Tabel 6. Perbandingan Mekanisme P2SPP

\begin{tabular}{|c|c|c|c|c|}
\hline Pembanding & Minahasa Selatan & Batanghari & Boyolali & Ngada \\
\hline $\begin{array}{l}\text { Minat } \\
\text { pemerintah }\end{array}$ & Ada & Ada & Ada & Ada \\
\hline $\begin{array}{l}\text { Hubungan } \\
\text { Pemda- } \\
\text { Konsultan } \\
\text { Pendamping }\end{array}$ & $\begin{array}{l}\text { Erat Konsultan } \\
\text { Pendamping - } \\
\text { Kadinas } \\
\text { Pemberdayaan } \\
\text { Masyarakat }\end{array}$ & $\begin{array}{l}\text { Erat Konsultan } \\
\text { Pendamping - } \\
\text { Kadinas } \\
\text { Pemberdayaan } \\
\text { Masyarakat -Staf } \\
\text { Pekerjaan Umum }\end{array}$ & \begin{tabular}{|l|} 
Erat Konsultan \\
Pendamping - \\
Kadinas \\
Pemberdayaan \\
Masyarakat-Bupati
\end{tabular} & \begin{tabular}{|l} 
Erat Konsultan \\
Pendamping - \\
Kadinas \\
Pemberdayaan \\
Masyarakat- \\
Bupati
\end{tabular} \\
\hline $\begin{array}{l}\text { Hubungan } \\
\text { Setrawan- } \\
\text { Konsultan } \\
\text { Pendamping } \\
\end{array}$ & $\begin{array}{l}\text { Konsultan } \\
\text { Pendamping } \\
\text { mendominasi } \\
\text { pekerjaan } \\
\end{array}$ & $\begin{array}{l}\text { Kerja lapangan oleh } \\
\text { setrawan kabupaten }\end{array}$ & $\begin{array}{l}\text { Konsultan } \\
\text { Pendamping } \\
\text { mendominasi } \\
\text { pekerjaan }\end{array}$ & $\begin{array}{l}\text { Kerja lapangan } \\
\text { oleh setrawan } \\
\text { kabupaten }\end{array}$ \\
\hline Susunan PTO & Mirip PTO pusat & Mirip PTO pusat & Mirip PTO pusat & Mirip PTO pusat \\
\hline $\begin{array}{l}\text { Kesesuaian } \\
\text { dengan PPK }\end{array}$ & $\begin{array}{l}\text { Penggalian gagasan } \\
\text { sampai } \\
\text { Musyawarah Antar } \\
\text { Desa }\end{array}$ & $\begin{array}{l}\text { Penggalian gagasan } \\
\text { sampai } \\
\text { Musyawarah Antar } \\
\text { Desa }\end{array}$ & $\begin{array}{l}\text { Penggalian gagasan } \\
\text { sampai } \\
\text { Musyawarah Antar } \\
\text { Desa }\end{array}$ & $\begin{array}{l}\text { Penggalian } \\
\text { gagasan sampai } \\
\text { Musyawarah } \\
\text { Antar Desa }\end{array}$ \\
\hline \begin{tabular}{|l} 
Cakupan \\
P2SPP \\
\end{tabular} & $\begin{array}{l}\text { Kecamatan non- } \\
\text { PPK }\end{array}$ & Seluruh kecamatan & Seluruh kecamatan & $\begin{array}{l}\text { Seluruh } \\
\text { kecamatan }\end{array}$ \\
\hline Sikap SKPD & $\begin{array}{l}\text { Peluang persaingan } \\
\text { SKPD }\end{array}$ & $\begin{array}{l}\text { Negosiasi dengan } \\
\text { masing-masing } \\
\text { SKPD }\end{array}$ & $\begin{array}{l}\text { Koordinasi SKPD } \\
\text { dalam musrenbang } \\
\text { kecamatan }\end{array}$ & $\begin{array}{l}\text { Koordinasi } \\
\text { SKPD dalam } \\
\text { musrenbang } \\
\text { kecamatan } \\
\end{array}$ \\
\hline Sikap DPRD & $\begin{array}{l}\text { Hubungan pribadi, } \\
\text { ada peluang } \\
\text { pemotongan } \\
\text { gagasan setelah } \\
\text { menjadi program } \\
\text { Pemda }\end{array}$ & $\begin{array}{l}\text { Koeksistensi, ada } \\
\text { peluang } \\
\text { pemotongan } \\
\text { gagasan }\end{array}$ & $\begin{array}{l}\text { Terpadu, tidak ada } \\
\text { peluang } \\
\text { pemotongan } \\
\text { proyek, persetujuan } \\
\text { Musrenbang } \\
\text { kecamatan sebagai } \\
\text { syarat persetujuan } \\
\text { proyek tingkat } \\
\text { kabupaten }\end{array}$ & $\begin{array}{l}\text { Terpadu, tidak } \\
\text { ada peluang } \\
\text { pemotongan } \\
\text { proyek, } \\
\text { persetujuan } \\
\text { Musrenbang } \\
\text { kecamatan } \\
\text { sebagai syarat } \\
\text { persetujuan } \\
\text { proyek tingkat } \\
\text { kabupaten } \\
\end{array}$ \\
\hline
\end{tabular}

Sebagaimana disampaikan di atas, sebagian bupati di daerah memiliki kegiatan untuk langsung berhubungan dengan masyarakat. Termasuk di dalam kegaitan ini ialah hubungan langsung antara bupati dan konsultan manajemen di tingkat kabupaten. Hal inilah yang terjadi di Kabupaten Boyolali (Jawa Tengah) dan Kabupaten Ngada. Hubungan langsung ini memperkuat posisi P2SPP, sehingga berpeluang untuk memperlancar mekanisme pelaksanaan P2SPP di daerah.

Dalam kondisi setrawan lemah, maka kerja pemberdayaan dan pengarsipannya dilaksanakan oleh konsultan PPK, baik fasilitator kecamatan (FK) maupun konsultan manajemen kabupaten (KM Kab). Hal ini terlihat pada Kabupaten Minahasa Selatan (Sulawesi Utara) dan Kabupaten Boyolali. Bentuknya di tingkat kecamatan berupa pengelolaan kecamatan setempat oleh FK yang bertugas di kecamatan lain, baik 
dalam bentuk pengelolaan kegiatan-kegiatan partisipatif maupun pengarsipannya. Di tingkat kabupaten pengarsipan sepenuhnya dilakukan oleh KM Kab.

Namun demikian, setrawan di Kabupaten Batanghari dan Kabupaten Ngada mampu menjalankan tugas di lapangan maupun pengarsipan secara mandiri. Di antara aparat pemerintah daerah sendiri pengarsipan tersebut dilaksanakan, tanpa bantuan dari KM KAb. Setrawan tersebut sudah mengetahui pola pengarsipan PPK sejak awal dilaksanakan di daerahnya, yang ternyata tidak berbeda jauh (nyaris sama sepenuhnya) dengan pengarsipan P2SPP.

Susunan PTO (Petunjuk Teknis Operasional) pada seluruh kasus P2SPP hampir sepenuhnya sama dengan PPK. Perbedaannya ialah pada penambahan mekanisme persaingan proposal kegiatan di tingkatk kabupaten. Perbedaannya lainnya hanya pada jenis kegiatan, misalnya di Batanghari dan Minahasa Selatan tertuju sematamata pada kegiatan fisik. Pada PTO PPK kegiatan dibagi menurut kegiatan fisik dan ekonomi.

Dengan struktur PTO P2SPP yang sama dengan PTO PPK, maka tidak mengherankan kesamaan mekanisme P2SPP dan PPK ialah selama masa penggalian gagasan di tingkat dusun sampai penyelenggaraan MAD (Musyawarah Antar Desa). Bagi pemerintah daerah sendiri, mekanisme tersebut dipandang efektif untuk mendapatkan usulan yang sesuai dengan kebutuhan masyarakat.

Peningkatan mekanisme kompetisi proposal dari tingkat kecamatan menuju tingkat kabupaten dipandang menimbulkan permasalahan struktural baru, yaitu munculnya pesaing baru pada forum SKPD. Lazim diketahui bahwa forum musrenbang di tingkat kabupaten merupakan forum persaingan di antara SKPD sendiri. Ketika usulan yang sudah menang di tingkat MAD dibawa ke tingkat kabupaten, di sana usulan tersebut kembali bersaing dengan program-progran yang sudah ditentukan oleh SKPD. Dalam periode sekarang, yaitu saat P2SPP masih dilaksanakan dalam bentuk proyek, persaingan tersebut tidak dipandang mengkhawatirkan. Ibaratnya, SKPD tidak terlalu mencampuri P2SPP yang akan didanai oleh proyek ini sendiri, sedangkan SKPK mengandalkan proyek yang didanai oleh APBD. Namun demikian, disadari bahwa manakala P2SPP nantinya sudah keluar dari keproyekan, dan masuk ke ranah pembangunan reguler, maka persaingan antara SKPD di tingkat kabupaten dengan usulan masyarakat di tingkat kecamatan akan sangat berat. Untuk mengatasi hal ini di Kabupaten Batanghari dibuka ruang negosiasi antara wakil kecamatan dan aparat SKPD mengenai pendanaan proyek-proyek yang tidak didanai oleh P2SPP. Bentuk penanggulangan yang bersifat struktural dijalankan di Kabupaten Boyolali dan Kabupaten Ngada. Di sana dikembangkan kesepakatan agar hanya usulan yang muncul dari musrenbang sejak kecamatanlah yang digunakan sebagai basis penyusunan APBD.

Dalam struktur pemerintah daerah terdapat unsur eksekutif dan legislatif. Kegiatan pembangunan di tingkat kabupaten membutuhkan pengesahan legal dari lembaga legislatif. Sebagian dari unsur legislatif tersebut pernah aktif dalam kegiatan PPK. Hubungan interpersonal inilah yang dikembangkan untuk memastikan bahwa alnggota legislatif mendukung kegiatan P2SPP, sebagaimana dilaksanakan di Kabupaten Minahasa Selatan dan Kabupaten Batanghari. Tentu saja hubungan personal ini tidak menjamin tiadanya campur tangan anggota legislatif yang memang 
sudah biasa dilakukan untuk memastikan suatu kegiatan (sebagaimana juga dilakukan oleh eksekutif).

\section{Kesimpulan}

Tidak ada perbedaan pola penanganan pembangunan partisipatif antara kabupaten peserta P2SPP dan kabupaten PPK non-P2SPP. Pembangunan partisipatif ternyata telah dipraktekkan dan dipelajari dari program-program pemberdayaan sejenis. Hal ini mudah dipahami, mengingat di Indonesia pemberdayaan telah tercakup dalam program-progranm pemerintah sejak tahun 1993, yaitu sejak penyelenggaraan Program IDT. Bahkan pola pembentukan kelompok masyarakat yang bersifat partisipatif telah muncul sejak penyelenggaraan program $\mathrm{P} 4 \mathrm{~K}$ untuk petani dan nelayan kecil sejak dekade 1980-an (Sajogyo, 2006). Secara khusus makna program pemberdayaan yang dipandang penting ialah bagian penggalian gagasan dan pelaksanaan kegiatan oleh masyarakat.

Penyelenggaraan pilot project P2SPP secara konseptual hendak memindahkan pola pandang sebagai berikut. Pertama, dari pemikiran zero sum game di dalam CDD (Community-Driven Development). CDD merupakan landasan konseptual yang dibangun oleh donor. Konsep ini didasarkan pada pemikiran rasionalitas-ekonomis. Salah satu ciri dari pengambilan keputusan rasional ialah zero sum game, di mana keputusan diambil di antara peluang yang lebih buruk; satu keputusan yang diambil sama dengan melepaskan alternatif keputusan yang lain. Dalam kaitan PPK, keputusan yang diambil ialah menghubungkan langsung pemerintah pusat kepada kelompok masyarakat. Alternatif yang dibuang ialah kerjasama dengan pemerintah daerah. Alternatif ini tidak digunakan karena diasumsikan kapasitas pemerintah daerah masih lemah

Kedua, menuju pemikiran-pemikiran berikut (tergantung kepada konstruksi yang hendak dibangun dalam P2SPP). Berbasis argumen proses, menuju proses manajerial pembangunan (perencanaan, pelaksanaan, dan monev) yang dilaksanakan oleh semua pihak di semua tingkatan (saat ini secara konseptual baru antara pemerintah dan rakyat, belum mencakup swasta). Argumen proses akan mendekati collaborative management di mana semua stakeholder yang ditemui akan diajak bekerjasama membangun wilayah setempat.

Berbasis argumen efisiensi-biaya, menuju peningkatan efisiensi proyek yang tidak hanya di tangan masyarakat, namun juga di tangan pemerintah daerah, dan selanjutnya di tangan pemerintah pusat. Argumen efisiensi-biaya ini mendekati good governance, di mana peran pemerintah berubah dari campur tangan menuju ketiadaan campur tangan terhadap pasar dan masyarakat

Berbasis argumen efektivitas, menuju diskusi kebutuhan dan tujuan dari agen pembangunan (masyarakat, pemerintah daerah, pemerintah pusat, swasta) di semua level pemerintahan (desa, kabupaten, propinsi, nasional). Sesungguhnya argumen inilah yang paling cocok untuk pemerintah. Argumen yang berorientasi kepada tujuan inilah yang mendekati appreciative inquiry (salah satu metode partisiaptif yang dikembangkan berbasis tujuan, bukan masalah pembangunan).

Berbasis argumen hak orang miskin, maka menuju orang miskin yang dipandang sebagai ahli/pakar dalam merumuskan masalah dan tujuan pembangunan bagi 
lapisan bawah. Pengembangan argumen ini lebih mendekati terwujudnya masyarakat sosialis

Selama ini P2SPP diletakkan di atas konteks PPK, atau memanfaatkan persepsi masyarakat dan pemerintah daerah bahwa "PPK Bagus". Hal ini terwujud dalam pemilihan lokasi pilot project di mana di sana terdapat sejarah pelaksanaan PPK yang tergolong sukses. Dalam proses pelepasan dari imej PPK seluruhnya menuju imej sendiri P2SPP muncullah pergeseran pemikiran pemaknaan, pertama, pada lokasi kasus yang masih transisional, muncul pemaknaan bahwa mekanisme persaingan (kompetisi) dalam P2SPP lebih sengit daripada PPK, karena berlangsung lebih lama dan pada level yang lebih tinggi yaitu sampai ke tingkat kabupaten. Pada fase transisional ini muncul persepsi bahwa P2SPP lebih berat dibandingkan PPK

Kedua, pada lokasi kasus yang mengalami perubahan kelembagaan secara final, P2SPP diwujudkan dalam sistem perencanaan partisipatif secara reguler hingga ke tingkat kabupaten. Oleh karena efektif menggali kebutuhan dari masyarakat dan mendiskusikannya dengan aparat pemerintah daerah, maka P2SPP dipandang lebih sesuai untuk pemerintah sekaligus masyarakat

Kelembagaan penting dalam proses perubahan makna di atas terletak pada penyelenggaraan musrenbang. Kelembagaan ini menjadi pengintegrasi mekanisme PPK, P2SPP, dan pola pembangunan reguler.

\section{DAFTAR PUSTAKA}

Cabannes, Y. 2004. "Participatory Budgeting: A Significant Contribution to Participatory Democracy", In: Environment and Urbanization Tahun 16 No. 27

Canadian International Development Agency. 1997. Mainstreaming Participatory Development: Experiences and Lessons of the Interagency Group on Participation. CIDA: Canada.

Chambers, R. 1987. Pembangunan Desa: Mulai dari Belakang. Terjemahan Putting the Last First. LP3ES: Jakarta.

Chambers, R. 1993. Challenging the Professions: Frontiers for Rural Development. Intermediate Tech.

Cooke, B., U. Kothari. 2001. The Case for Participation as Tyranny, In: B. Cooke, U. Kothari, eds. Participation: The New Tyranny? Zed Books: London.

Cornwall, A. 2000. Making a Difference? Gender and Participatory Development. IDS Discussion Paper No. 378.

Dongier, P, JV Domelen, E Ostrom, A Ryan, W Wakeman, A Bebbington, S Alkire, T Esmail, M Polski. 2003. Community-Driven Development. World Bank: Washington DC.

Escobar, A. 2005. Imagining Post-Development Era. In: M. Edelman, A. Haugerud, eds. The Anthropology of Development and Globalization. Blackwell: Malden, MA 
Esteva, G. 1992. Development, In:W. Sachs, ed. The Development Dictionary: A Guide to Knowledge as Power. Zed Books: London.

Francis, P. 2004. Participatory Development at the World Bank: the Primacy of Process. In: B. Cooke, U. Kothari, eds. Participation: The New Tyranny? Zed Books: London.

Friedmann, J. 1992. Empowerment: The Politics of Alternative Development. Blackwell: Cambridge.

Ife, J. 1995. Community Development: Creating Community Alternatives - Vision, Analysis and Practice. Longman. Australia.

Jennings, R. 2000. Participatory Development as New Paradigm: The Transition of Development Professionalism. Makalah di sampaikan dalam konferensi Community Based Reintegration and Rehabilitation in Post-Conflict Settings, Washington, DC, Oktober 2000.

Kuhn, TS. 2002. The Structure of Scientific Revolution: Peran Paradigma dalam Revolusi Sains. Terjemahan The Structure of Scientific Revolution oleh Tjun Surjaman. Remaja Rosdakarya: Bandung.

Kumar, S, 2002, Methods for Community Participation: A Complete Guide for Practitioners, ITDG: London.

McMichael, P. 2003. Development and Social Change : A Global Perspective. Pine Forge: Thousand Oaks.

Miraftab, F. 2003. "The Perils of Participatory Discourse: Housing Policy in Postapartheid South Africa", In: Journal of Planning Education and Research Tahun 22 No. 226

Mohan, G. 2004. Beyond Participation: Strategies for Deeper Empowerment. In: B. Cooke, U. Kothari, eds. Participation: The New Tyranny? Zed Books: London.

Mosse, D. 2004. "People Knowledge”, Participation and Patronage: Operations and Representations in Rural Development. In: B. Cooke, U. Kothari, eds. Participation: The New Tyranny? Zed Books: London.

Rahnema, M. 1992. Participation, In: W. Sachs, ed. The Development Dictionary: A Guide to Knowledge as Power. Zed Books: London.

Sajogyo. 2006. Ekososiologi: Deideologisasi Teori, Restrukturisasi Aksi (Petani dan Perdesaan sebagai Kasus Uji). Cindelaras: Yogyakarta.

Sanderson, E, S. Kindon. 2004. "Progress in Participatory Development: Opening up The Possibility of Knowledge Through Progressive Participation", In: Progress in Development Studies Tahun 4 No. 114

Siregar, B.B, Wahono, eds. 2002. Kembali ke Akar: Kembali ke Konsep Otonomi Komunitas Adat. Forum Pengembangan Partisipasi Masyarakat: Jakarta.

The Liang Gie. 1993. Pertumbuhan Pemerintahan Daerah di Negara Republik Indonesia, Jilid I, Edisi Kedua (Diperlengkap). Liberty: Yogyakarta. 
Thomas, A. 2002. Meanings and Views of Development. In: T. Allen, A. Thomas, eds. Poverty and Development: Into the 21st Century. Oxford Univ. Pr.: Oxford.

United States Agency for International Development. 1999. Participation at USAID: Stories, Lessons and Challenges. USAID Participation Forum Summaries: Washington, DC.

World Bank. 1996. The World Bank Participation Sourcebook. World Bank: Washington, DC.

World Bank Operations Policy Department. 1994. The World Bank and Participation. World Bank: Washington, DC. 
